\title{
Fragments from the Author's Preface
}

[Among the author's papers were several fragments, partly written in pencil, bearing the notation "for the preface," and evidently intended to be worked into a final draft. He may have wished to say more; all we found is presented below. - Ed.]

THE AUTHOR of the present volume, in his early seventies, may make use of the privilege, usually granted to men in the prime of their senility, to say a few words about himself, in this case the sources of his interest in the Huns. All my life I have been fascinated by the problems of the frontier. As a boy I dug Roman copper coins along the remnants of the earthen walls that, as late as the seventeenth century, protected Vienna, my native town, from the East. Two blocks from the house in which I was born there still stood in my youth a house above whose gate a Turkish stone cannon ball from the siege of 1529 was immured. My grandfather spent a year in jail for fighting in 1848 with the revolutionaries against the Croatian mercenaries of the Habsburgs. My doctoral dissertation dealt with the "barbarian" elements in Han lore. In 1929 I lived for months in the tents of Turkishspeaking nomads in northwestern Mongolia, where the clash between "higher civilization," represented by Tibetan Lamaism, and the "primitive" beliefs of the Turks was strikingly visible. In Kashmir, at Harwan, I marveled at the artificially deformed skulls on the stamped tiles of Kushan times, those skulls that had impressed me so much when I first saw them in the museum in Vienna and that I had measured as a student. In Nepal I had another chance to see the merging of different civilizations in a borderland. I spent many days in the museum at Minusinsk in southern Siberia studying the "Scythian" bronze plaques and cauldrons. In Kabul I stood in awe before the inscription from Surkh Kotal: it brought back to me the problems of 
the barbarians at China's border about which I had written a good deal in previous years. Attila and his avatars have been haunting me as far back as I can recall.

In the history of the Western world the eighty years of Hun power were an episode. The Fathers assembled in council at Chalcedon showed a sublime indifference to the barbarian horsemen who, only a hundred miles away, were ravaging Thrace. They were right. A few years later, the head of Attila's son was carried in triumphal procession through the main street of Constantinople.

Some authors have felt that they had to justify their studies of the Huns by speculating on their role in the transition from late antiquity to the Middle Ages. Without the Huns, it has been maintained, Gaul, Spain, and Africa would not, or not so soon, have fallen to the Germans. The mere existence of the Huns in eastern Central Europe is said to have retarded the feudalization of Byzantium. This may or may not be true. But if a historical phenomenon were worth our attention only if it shaped what came after it, the Mayans and Aztecs, the Vandals in Africa, the Burgundians, the Albigenses, and the crusaders' kingdoms in Greece and Syria would have to be wiped off the table of Clio. It is doubtful that Attila "made history." The Huns "perished like the Avars" - "sginuli kak obry," as the old Russian chroniclers used to say when they wrote about a people that had disappeared forever.

It seems strange, therefore, that the Huns, even after fifteen hundred years, can stir up so much emotion. Pious souls still shudder when they think of Attila, the Scourge of God; and in their daydreams German university professors trot behind Hegel's Weltgeist zu Pferde. They can be passed over. But some Turks and Hungarians are still singing loud paeans in praise of their great ancestor, pacifier of the world, and Gandhi all in one. The most passionate Hun fighters, however, are the Soviet historians. They curse the Huns as if they had ridden, looting and killing, through the Ukraine only the other day; some scholars in Kiev cannot get over the brutal destruction of the "first flowering of Slavic civilization."

The same fierce hatred burned in Ammianus Marcellinus. He and the other writers of the fourth and fifth centuries depicted the Huns as the savage monsters which we still see today. Hatred and fear distorted the picture of the Huns from the moment they appeared on the lower Danube. Unless this tendentiousness is fully understood - and it rarely is - the literary evidence is bound to be misread. The present study begins, therefore, 'with its reexamination.

The following chapters, dealing with the political history of the Huns, are not a narrative. The story of Attila's raids into Gaul and Italy need not be told once more; it can be found in any standard history of the declining 
Roman Empire, knowledge of which, at least in its outlines, is here taken for granted. However, many problems were not even touched on and many mistakes were made by Bury, Seeck, and Stein. This statement does not reflect on the stature of these eminent scholars, for the Huns were on the periphery of their interests. But such deficiencies are true also for books which give the Huns more room, and even for monographs. The first forty or fifty years of Hun history are treated in a cursory manner. The sources are certainly scanty though not as scanty as one might believe; for the invasion of Asia in 395, for instance, the Syriac sources flow copiously. Some of the questions that the reign of Attila poses will forever remain unanswered. Others, however, are answered by the sources, provided one looks, as I have, for sources outside the literature that has been the stock of Hunnic studies since Gibbon and Le Nain de Tillemont. The discussions of chronology may at times tax the patience of the reader, but that cannot be helped. Eunapius, who in his Historical Notes also wrote about the Huns, once asked what bearing on the true subject of history inheres in the knowledge that the battle of Salamis was won by the Hellenes at the rising of the Dog Star. Eunapius has his disciples in our days also, and perhaps more of them than ever. One can only hope that we will be spared a historian who does not care whether Pearl Harbor came before or after the invasion of Normandy because "in a higher sense" it does not matter.

The second part of the present book consists if monographs on the economy, society, warfare, art, and religion of the Huns. What distinguishes these studies from previous treatments is the extensive use of archaeological material. In his Attila and the Huns Thompson refuses to take cognizance of it, and the little to which Altheim refers in Geschichte der Hunnen he knows at second hand. The material, scattered through Russian, Ukrainian, Rumanian, Hungarian, Chinese, Japanese, and latterly also Mongolian publications, is enormous. In recent years archaeological research has been progressing at such speed that I had to modify my views repeatedly while I was working on these studies. Werner's monumental book on the archaeology of Attila's empire, published in 1956, is already obsolete in some parts. I expect, and hope, that the same will be true of my own studies ten years from now.

Although aware of the dangers in looking for parallels between the Huns and former and later nomads of the Eurasian steppes, I confess that my views are to a certain, I hope not undue, degree influenced by my experiences with the Tuvans in northwestern Mongolia, among whom I spent the summer of 1929. They are, or were at that time, the most primitive Turkish-speaking people at the borders of the Gobi. 
I possibly will be criticized for paying too little attention to what Robert Göbl calls the Iranian Huns: Kidara, White Huns, Hepthalites, and Hunas. In discussing the name "Hun" I could not help speculating on their names. But this was as far as I dared go. The literature on these tribes or peoples is enormous. They stand in the center of Altheim's Geschichte der Hunnen, although he practically ignores the numismatic and Chinese evidence, on which Enoki has been working for so many years. Göbl's Dokumente zur Geschichte der iranischen Hunnen in Baktrien und Indien is the most thorough study of their coins and seals and, on this basis, of their political history. And yet, there remain problems to whose solution I could not make a meaningful contribution. I have neither the linguistic nor the paleographic knowledge to judge the correctness of the various, often entirely different, readings of the coin legends. But even if someday scholars wrestling with this recalcitrant material do come to an agreement, the result will be relatively modest. The Huna Mihirakula and Toramana will remain mere names. No settlement, no grave, not so much as a dagger or a piece of metal exists that could be ascribed to them or any other Iranian Huns. Until the scanty and contradictory descriptions of their life can be substantially supplemented by finds, the student of the Attilanic Huns will thankfully take cognizance of what the students of the so-called Iranian Huns can offer him; but there is little he can use for his research. A recently discovered wall painting in Afrosiab, the ancient Samarkand, seems to show the first light in the darkness. The future of the Hephthalite studies lies in the hands of the Soviet and, it is hoped, the Chinese archaeologists. ' $E v \beta v \theta \tilde{\omega} \gamma \dot{\alpha} \varrho \dot{\eta} \dot{\alpha} \lambda \eta^{\prime} \theta \varepsilon \iota \alpha$.

I am aware that some chapters are not easy reading. For example, the one on the Huns after Attila's death draws attention to events seemingly not worth knowing, to men who were mere shadows; it jumps from Germanic sagas to ecclesiastical troubles in Alexandria, from the Iranian names of obscure chieftains to an earthquake in Hungary, from priests of Isis in Nubia to Middle Street in Constantinople. I will not apologize. Some readers surely will find the putting together of the scattered pieces as fascinating as I did, and I frivolously confess to an artistic hedonism which to me is not the least stimulus for my preoccupation with the Dark Ages. On a higher level, to pacify those who, with a bad conscience, justify what they are doing - Historical Research with capital letters - may I point out that I fail to see why the history of, say, Baja California is more respectable than, say, that of the Huns in the Balkans in the 460's. Sub specie aeternitatis, both dwindle into nothingness.

Anatole France, in his Opinions of Jérôme Coignard, once told the wonderful story of the young Persian prince Zémire, who ordered his scholars to 
write the history of mankind, so that he would make fewer errors as a monarch enlightened by past experience. After twenty years, the wise men appeared before the prince, king by then, followed by a caravan composed of twelve camels each bearing 500 volumes. The king asked them for a shorter version, and they returned after another twenty years with three camel loads, and, when again rejected by the king, after ten more years with a single elephant load. After yet five further years a scholar appeared with a single big book carried by a donkey. The king was on his death bed and sighed, "I shall die without knowing the history of mankind. Abridge, abridge !" "Sire," replied the scholar, "I will sum it up for you in three words: They were born, they suffered, they died !"

In his way, the king, who did not want to hear it all, was right. But as long as men, stupidly perhaps, want to know "how it was," there may be a place for studies like the present one. Dixi et salvavi animam meam ....

O. M.-H. 
